\title{
Peningkatan Prestasi Belajar Mata Pelajaran PPKN Melalui Model Pembelajaran Student Teams Achievement Division (Stad) pada Siswa Kelas Viii Smp Labschool Pulau Arar Kabupaten Sorong
}

\author{
Roni Andri Pramita \\ e-mail: ronyandry990@gmail.com \\ Universitas Pendidikan Muhammadiyah Sorong
}

\begin{abstract}
Abstrak : Dalam pelaksanaan proses pembelajaran guru memilih dan menggunakan strategi, model dan media pembelajaran salah satunya yaitu dengan model pembelajaran STAD. Penelitian ini bertujuan untuk meningkatkan prestasi belajar PPKn. Subjek penelitian ini adalah siswa kelas VIII SMP Lab School Pulau Arar yang berjumlah 20 siswa. Bentuk penelitian ini adalah penelitian tindakan kelas (PTK). Teknik pengumpulan data yang digunakan adalah melalui teknik tes dan teknik non tes. Teknik non tes yang digunakan adalah pengamatan, angket, dan dokumentasi. Prosedur penelitian meliputi tahap: membuat rencana penelitian, merencanakan tindakan, pengamatan, dan merefleksikan. Proses penelitian ini dilaksanakan dalam dua siklus. Hasil penelitian menunjukkan adanya peningkatan prestasi belajar siswa. Adapun peningkatan hasil pembelajaran dapat dilihat dari perolehan nilai siswa dalam prestasi belajar siswa dari siklus I dan Siklus II. Pada siklus I prosentase ketuntasan hasil belajar siswa dalam pelajaran PPKn sebesar $40 \%$ atau 8 siswa dan pada siklus II sebesar $90 \%$ atau 18 siswa. Hal ini membuktikan bahwa dengan penerapan model pembelajaran STAD dapat meningkatkan prestasi belajar siswa pada mata pelajaran pendidikan pancasila dan Kewarganegaraan.
\end{abstract}

Kata kunci : Prestasi belajar siswa, model pembelajaran STAD

\section{Pendahuluan}

Pendidikan pancasila dan Kewarganegaraan adalah wahana untuk mengembangkan dan melestarikan nilai luhur yang berakar pada budaya bangsa Indonesia yang diharapkan dapat diwujudkan dalam bentuk perilaku kehidupan sehari-hari peserta didik. Dalam pembelajaran di sekolah-sekolah, PPKn diajarkan bukan sekedar sebagai pengetahuan saja, melainkan sebagai sumber penanaman kepribadian pada diri peserta didik untuk lebih memahami dan mengerti tentang moral-moral dan norma-norma dalam kehidupan seharihari, baik dilingkungan keluarga, sekolah, masyarakat, maupun dalam kehidupan berbangsa dan bernegara.

Guru harus selalu meningkatkan mutu pembelajarannya dimulai dengan rancangan pembelajaran yang baik dengan memperhatikan tujuan, karakteristik peserta didik, materi yang diajarkan serta sumber belajar yang tersedia hal ini dilakukan agar peserta didik memiliki kemampuan memahami dan menerapkan materi yang diajarkan dalam kehidupan sehari-hari. Peserta didik dianggap menguasai materi yang diajarkan yaitu dengan ditandai kemampuan peserta didik tersebut dapat mencapai indikator yang telah ditetapkan dalam 
silabus. Dalam proses belajar mengajar masih banyak guru yang menggunakan metode yang kurang menarik sehingga hasil belajar yang dicapai tidak optimal. Rendahnya perolehan hasil belajar peserta didik menunjukkan adanya indikasi terhadap rendahnya kinerja belajar peserta didik dan metode yang digunakan untuk mengajar kurang cocok.

Untuk meningkatkan hasil belajar peserta didik, guru harus mampu menemukan ideide yang baru dan dapat mendesain pembelajaran sebagaimana yang diharapkan peserta didik sehingga permasalahan tersebut dapat teratasi. Model pembelajaran yang inovatif diyakini mampu mengembangkan sikap, keterampilan, dan pengetahuan peserta didik. Tidak sedikit peserta didik yang mengalami hambatan dalam mengembangkan pelajaran PPKn. Hal ini juga yang dialami peserta didik kelas VIIII SMP Lab. School Pulau Arar. Peserta didik tidak antusias selama proses belajar mengajar berlangsung, peserta didik kurang dapat mengembangkan ide-ide dan kreativitas mereka. Selain itu, strategi pembelajaran yang kurang mengena terhadap pembelajaran PPKn dalam meningkatkan pemahaman peserta didik terhadap pembelajaran PPKn. Untuk dapat menciptakan aktivitas pembelajaran yang berkualitas, langkah awal yang harus dilakukan guru adalah menerapkan desain pembelajaran.

Dalam penelitian ini penulis menerapkan model pembelajaran kooperatif tipe STAD (Student Teams Achievement Divisions) yaitu Tim Siswa Kelompok Prestasi. Pembelajaran Kooperatif tipe STAD merupakan salah satu fariasi dari model pembelajaran Kooperatif (Cooperative Learning). Model pembelajaran ini mengajak peserta didik bekerja sama untuk belajar dan bertanggung jawab pada kemajuan belajar teman. Disini peserta didik bekerja sama dalam memahami pelajaran.

Meningkatkan prestasi belajar PPKn dengan kompetensi dasar pancasila sebagai dasar negara dan pandangan hidup bangsa melalui model pembelajaran Student Teams Achievement Division (STAD) diasumsikan dapat mengatasi permasalahan peserta didik dalam pembelajaran PPKn. Oleh karena itu, peneliti melakukan penelitian tindakan kelas dengan judul "Meningkatkan Prestasi Belajar PPKn Melalui Model Pembelajaran Student Teams Achievement Division (STAD) pada Siswa Kelas VIIII Semester Ganjil SMP Lab. School Pulau Arar Kabupaten Sorong Tahun Ajaran 2018/2019." dengan materi pancasila sebagai dasar negara.

\section{Metode Penelitian}

Rancangan penelitian yang digunakan dalam penelitian ini adalah penelitian tindakan kelas (Classroom Action Research). Tujuan menggunakan rancangan tersebut adalah untuk meningkatkan prestasi belajar PPKn dengan kompetensi dasar pancasila sebagai dasar negara dan pandangan hidup bangsa melalui model pembelajaran koopertif tipe STAD pada siswa kelas VIII SMP Lab. School Pulau Arar.

Penelitian Tindakan Kelas ini dilakukan di SMP Lab. School Pulau Arar dengan mengambil subjek penelitian pada siswa kelas VIII sebanyak 20 siswa. Pemilihan tempat penelitian ini didasarkan atas pertimbangan bahwa pertama, peneliti pernah bertugas di sekolah tersebut dan mengetahui kemampuan siswanya. Kedua, berdasarkan pengalaman guru di sekolah, prestasi belajar PPKn pada siswa kelas VIII SMP Lab. School Pulau Arar 
masih rendah. Penelitian ini dilaksanakan selama empat bulan yaitu dari bulan Juli sampai bulan Oktober tahun 2018.

Prosedur Penelitian Tindakan Kelas yang dilakukan dalam penelitian ini meliputi; (1) membuat rencana penelitian, (2) merencanakan tindakan, (3) pengamatan, (4) merefleksikan. Prosedur penelitian dimulai dengan siklus pertama, apabila telah diketahui tingkat keberhasilannya, maka ditentukan rancangan tindakan siklus kedua. Siklus kedua merupakan kelanjutan dari siklus pertama yang pelaksanaannya disertai dengan berbagai perbaikan terhadap hambatan yang ditemukan dalam siklus pertama.

Teknik pengumpulan data yang digunakan dalam penelitian ini ada dua cara yaitu teknik tes dan non tes. Teknik tes yang digunakan dalam penelitian ini yaitu pelaksanaan tes awal dan tes akhir. Tes awal dilakukan sekali pada awal sebelum pelaksanaan siklus I untuk mengetahui keterampilan siswa dalam pembelajaran PPKn sebelum menerapkan model pembelajaran kooperatif STAD. Setelah itu pada akhir setiap siklus yang dilaksanakan diadakan tes akhir. Tes akhir dilakukan dengan memberikan butir soal kepada siswa. Tes ini untuk mengetahui kemampuan siswa dalam pembelajaran PPKn. Teknis non tes yang digunakan adalah pengamatan, angket (kuisioner), dan dokumentasi foto.

1. Pengamatan

Dalam fase ini, observer (pengamat) mengamati proses pembelajaran dan mengumpulkan data mengenai segala sesuatu yang terjadi pada proses pembelajaran tersebut, baik yang terjadi pada siswa maupun situasi di dalam kelas. Pengamatan dilakukan dengan bantuan salah seorang rekan. Pelaksanaan pengamatan mulai awal pembelajaran ketika guru melakukan apersepsi sampai akhir pembelajaran. Pengamatan yang dilakukan meliputi rencana pelaksanaan pembelajaran (RPP), dan pelaksanaan pembelajaran kooperatif tipe STAD. Pengamatan terhadap siswa dilakukan untuk mengetahui sikap dan perilaku siswa terhadap pembelajaran PPKn dengan menerapkan model pembelajaran kooperatif tipe STAD.

2. Angket

Angket merupakan suatu teknik pengumpulan data secara tidak langsung (peneliti tidak langsung bertanya jawab dengan responden). Instrument atau alat pengumpulan datanya juga disebut angket berisi sejumlah pertanyaan-pertanyaan yang harus dijawab atau direspon oleh responden. Responden mempunyai kebebasan untuk memberikan jawaban atau respon sesuai dengan persepsinya. Setiap akhir pembelajaran siswa mengisi angket. Angket ini berisi respon siswa terhadap model pembelajaran kooperatif tipe STAD, meliputi: minat, motivasi belajar, prestasi belajar, dan kerja sama dalam kelompok.

3. Dokumen Foto

Pengambilan data melalui dokumentasi foto dilakukan saat proses pembelajaran berlangsung. Peneliti meminta bantuan pada rekan sejawat untuk mengambil foto. Dokumen foto yang diambil untuk memperoleh data tentang:

1. Aktivitas siswa ketika mendengarkan penjelasan materi pembelajaran PPKn dPengan kompetensi dasar pancasila sebagai dasar negara dan pandangan hidup bangsa.

2. Aktivitas siswa ketika berdiskusi tentang materi pembelajaran (tugas yang diberikan guru kepada masing-masing kelompok).

3. Aktivitas guru ketika membimbing siswa dalam mengerjakan tugas / berdiskusi kelompok. 


\section{Pembahasan Hasil Penelitian}

Dari hasil pengamatan yang dilakukan peneliti, prestasi belajar PPKn siswa kelas VII di SMP Lab. School Pulau Arar dikatakan rendah karena belum ada siswa yang nilainya memenuhi Kriteria Ketuntasan Minimal (KKM) yaitu 7,5 yang merupakan Kriteria Ketuntasan Minimal (KKM) yang telah ditentukan sekolah. Rata-rata yang diperoleh dari hasil tes kondisi awal adalah 38,5. Hal ini disebabkan karena siswa belum antusias mengikuti pembelajaran PPKn, siswa masih pasif dan kurang aktif dalam mengikuti proses belajar mengajar. Hal ini apabila tidak ditindaklanjuti tentu akan mengakibatkan proses belajar mengajar tidak optimal dan mempengaruhi prestasi belajar.

\section{Hasil Angket Respon Siswa pada Kondisi Awal}

Sebelum penelitian tindakan dilaksanakan terlebih dahulu dilakukan pengamatan awal, peneliti membagikan angket kepada siswa untuk diisi oleh masing-masing siswa agar mengetahui kondisi awal dan antusias siswa terhadap pembelajaran PPKn yang ada di kelas. Hasil dari angket respon siswa adalah sebagai berikut:

Tabel 1. Hasil Angket Respon Siswa

\begin{tabular}{|c|c|c|c|}
\hline \multirow[b]{2}{*}{ Aspek Yang Diamati } & \multirow{2}{*}{$\begin{array}{c}\text { Jumlah } \\
\text { Siswa Total }\end{array}$} & \multicolumn{2}{|c|}{ Respon Siswa } \\
\hline & & $\begin{array}{c}\text { Jumlah } \\
\text { Siswa }\end{array}$ & $\begin{array}{c}\text { Prosentase } \\
(\%)\end{array}$ \\
\hline Saya senang dengan pelajaran PKn & 20 & 13 & 65 \\
\hline Pelajaran PKn menyenangkan & 20 & 6 & 30 \\
\hline $\begin{array}{l}\text { Dengan belajar PKn saya menjadi } \\
\text { bersemangat }\end{array}$ & 20 & 5 & 25 \\
\hline $\begin{array}{l}\text { Saya senang dengan metode diskusi dan } \\
\text { pemberian tugas }\end{array}$ & 20 & 8 & 40 \\
\hline $\begin{array}{l}\text { Dengan pembelajaran diskusi kelompok } \\
\text { saya bisa mengerjakan soal PKn }\end{array}$ & 20 & 4 & 20 \\
\hline
\end{tabular}

Dari tabel dapat diketahui bahwa siswa yang senang dengan pelajaran PPKn sebanyak 65\%, menyetujui bahwa pelajaran PPKn menyenangkan sebanyak 30\%, menyetujui bahwa dengan belajar PPKn menjadi bersemangat sebanyak 25\%, yang senang dengan metode diskusi dan pemberian tugas sebanyak 40\%. Yang menyetujui bahwa dengan diskusi bisa mengerjakan soal PPKn sebanyak 20\%. Melihat kondisi kelas yang demikian, maka perlu dilakukan perbaikan terhadap media pembelajaran yang kurang melibatkan partisipasi aktif siswa. Salah satu media yang dapat dijadikan alternatif agar siswa dapat ikut berpartisipasi aktif dan antusias mengikuti proses belajar mengajar terutama pada mata pelajaran PPKn adalah menggunakan model pembelajaran yang bervariasi, salah satunya yaitu menggunakan model pembelajaran kooperatif tipe STAD (Student Teams Achivement Division). 
Agar mempermudah dalam pelaksanaan tindakan maka perlu dibuat suatu perencanaan. Perencanaan yang dibuat meliputi: membuat RPP dengan materi yang akan diajarkan, membuat lembar observasi untuk mengamati partisipasi aktif siswa dalam mengikuti pembelajaran PPKn, membuat angket respon siswa untuk mengetahui antusias siswa terhadap mata pelajaran PKn, menyiapkan strategi model pembelajaran STAD dalam rangka mencapai tujuan pembelajaran.

Melalui perencanaan sebelum melakukan tindakan akan mempermudah dalam menentukan keberhasilan tindakan yang akan dilaksanakan. Perencanaan dapat dijadikan panduan pelaksanaan tindakan, sehingga peneltian yang dilakukan tidak jauh melenceng dari tujuan penelitian untuk menerapkan model pembelajaran STAD dalam rangka meningkatkan prestasi belajar PPKn pada siswa kelas Kelas VIII SMP Lab. School Pulau Arar.

\section{Hasil Tindakan Siklus 1}

\section{Perencanaan Tindakan}

Perencanaan tindakan yang dilakukan pada siklus 1adalah sebagai berikut:

a) Membuat Rencana Pelaksanaan Pembelajaran (RPP) tentang materi yang akan diajarkan yaitu persamaan kedudukan warga negara. Rencana Pelaksanaan Pembelajaran ini disusun sebagai pedoman peneliti dalam melaksanakan kegiatan pembelajaran di dalam kelas.

b) Menyusun dan menyiapkan lembar angket respon siswa untuk mengetahui antusias siswa terhadap mata pelajaran PKn. Lembar ini akan diisi oleh masing-masing siswa pada setiap pertemuan yaitu mulai kondisi awal, siklus 1dan siklus II yang dibuat oleh peneliti.

c) Menyusun dan menyiapkan lembar observasi untuk mengetahui partisipasi aktif siswa selama proses belajar mengajar berlangsung. Lembar observasi ini diguanakan sebagai pedoman peneliti di dalam mengamati aktivitas siswa di dalam kelas. Lembar ini diisi oleh peneliti pada setiap pertemuan yaitu pada siklus 1 dan siklus II yang dibuat oleh peneliti.

d) Menyusun dan mempersiapkan soal-soal yang digunakan untuk mengukur prestasi belajar siswa setelah proses pembelajaran menggunakan model pembelajaran STAD berlangsung.

e) Mempersiapkan model pembelajaran kooperatif tipe STAD (Student Teams Achivement Division).

\section{Pelaksanaan Tindakan pada Siklus 1}

Langkah-langkah pelaksanaan tindakan pada siklus 1 adalah sebagai berikut:

1) Kegiatan Awal

a. Guru membuka pelajaran, mengawali dengan salam, mengabsen siswa, dan mengkondisikan kelas.

b. Guru memberikan motivasi dan mengajukkan pertanyaan yang berkaitan dengan materi pelajaran.

c. Guru menyampaikan kompetensi dasar dan tujuan pembelajaran.

d. Guru menyampaikan kegiatan yang meliputi kegiatan mengamati, menanya dan mengkomunikasikan. 
e. Guru membagi siswa dalam beberapa kelompok yang tediri dari 4-5 orang.

f. Siswa menyimak penjelasan guru tentang model pembelajaran STAD.

2) Kegiatan Inti

a. Siswa mendengarkan penjelasan guru tentang materi persamaan kedudukan warga negara.

b. Siswa dengan difasilitasi oleh guru berdiskusi dengan kelompok masing-masing dan mengerjakan tugas yang diberikan guru.

c. Guru membimbing masing-masing kelompok untuk mengerjakan tugas yang diberikan kepada siswa.

d. Guru meminta siswa yang sudah bisa mengerjakan soal untuk menjelaskan kepada teman kelompoknya.

e. Guru member pertanyaan kepada seluruh siswa, pada saat menjawab siswa tidak boleh saling membantu.

f. Bersama-sama dengan peserta didik dan/atau sendiri membuat simpulan pelajaran.

3) Penutup

a. Melakukan penilaian dan/atau refleksi terhadap kegiatan yang sudah dilaksanakan.

b. Guru memberikan umpan balik positif dan penguatan dalam bentuk lisan, isyarat, maupun hadiah terhadap keberhasilan siswa.

c. Guru bersama siswa membaca do'a dan memberi salam.

\section{Hasil Angket Respon Siswa pada Siklus 1}

Pada siklus 1 peneliti kembali membagikan angket respon siswa untuk mengetahui peningkatan antusias siswa terhadap mata pelajaran PKn yang akan diisi oleh setiap siswa. Berikut adalah hasil angket respon siswa: 
Tabel 2. Hasil Angket Respon Siswa pada Siklus 1

\begin{tabular}{|c|c|c|c|}
\hline \multirow[b]{2}{*}{ Aspek Yang Diamati } & \multirow{2}{*}{$\begin{array}{c}\text { Jumlah } \\
\text { Siswa Total }\end{array}$} & \multicolumn{2}{|c|}{ Partisipasi Aktif } \\
\hline & & $\begin{array}{l}\text { Jumlah } \\
\text { Siswa }\end{array}$ & $\begin{array}{c}\text { Prosentase } \\
(\%)\end{array}$ \\
\hline Saya senang dengan pelajaran PKn & 20 & 15 & 75 \\
\hline Pelajaran PKn menyenangkan & 20 & 14 & 70 \\
\hline $\begin{array}{l}\text { Dengan belajar PKn saya menjadi } \\
\text { bersemangat }\end{array}$ & 20 & 8 & 40 \\
\hline $\begin{array}{l}\text { Saya senang dengan metode diskusi dan } \\
\text { pemberian tugas }\end{array}$ & 20 & 11 & 55 \\
\hline $\begin{array}{l}\text { Dengan pembelajaran diskusi kelompok } \\
\text { saya bisa mengerjakan soal } \mathrm{PKn}\end{array}$ & 20 & 10 & 50 \\
\hline $\begin{array}{l}\text { Model pembelajaran STAD sangat } \\
\text { cocok pada mata pelajaran PKn }\end{array}$ & 20 & 12 & 60 \\
\hline $\begin{array}{l}\text { Dengan diberinya model pembelajaran } \\
\text { STAD saya merasa sangat percaya diri }\end{array}$ & 20 & 8 & 40 \\
\hline $\begin{array}{l}\text { Saya terdorong untuk belajar dengan } \\
\text { menggunakan model pembelajaran } \\
\text { STAD }\end{array}$ & 20 & 8 & 40 \\
\hline $\begin{array}{l}\text { Dengan diterapkan model pembelajaran } \\
\text { STAD disiplin masuk sekolah } \\
\text { bertambah }\end{array}$ & 20 & 5 & 25 \\
\hline $\begin{array}{l}\text { Jika guru memberikan penghargaan / } \\
\text { reward terhadap pertanyaan, jawaban } \\
\text { dan hasil ulangan saya meningkat dan } \\
\text { belajar saya makin semangat }\end{array}$ & 20 & 13 & 65 \\
\hline
\end{tabular}

Dari data tabel di atas diketahui bahwa siswa yang senang dengan pelajaran PPKn sebanyak $75 \%$, pada kondisi awal sebanyak $65 \%$. Hal ini menunjukkan adanya peningkatan sebesar $10 \%$. Siswa yang menyetujui bahwa pelajaran PPKn menyenangkan sebanyak $70 \%$, pada kondisi awal sebanyak 30\%, terjadi peningkatan sebanyak $40 \%$. Siswa yang menyetujui bahwa dengan belajar PPKn menjadi bersemangat sebanyak 40\%, pada kondisi awal sebanyak $25 \%$. Ini menunjukkan adanya peningkatan sebesar $15 \%$. Siswa yang senang dengan metode diskusi dan pemberian tugas sebanyak 55\%, pada kondisi awal sebanyak $40 \%$, hal ini menunjukkan adanya peningkatan sebesar $15 \%$. Siswa yang menyetujui bahwa dengan pembelajaran model STAD bisa mengerjakan soal PPKn sebanyak 50\%, pada kondisi awal yang menggunakan sebanyak 20\%. Hal ini menunjukkan bahwa setelah diterapkan model pembelajaran STAD sedikit ada peningkatan sebesar 30\%.

Siswa yang menyetujui bahwa model pembelajaran STAD sangat cocok pada mata pelajaran PPKn sebanyak 60\%, siswa yang menyetujui bahwa dengan model pembelajaran STAD merasa percaya diri sebanyak $60 \%$, siswa yang terdorong untuk belajar menggunakan model pembelajaran STAD sebanyak 40\%, siswa yang bertambah menjadi disiplin masuk sekolah sebanyak $25 \%$, dan siswa yang menjadi semangat belajar dan hasil nilai ulangannya meningkat setelah guru memberikan penghargaan sebanyak $65 \%$.

\section{Hasil Tes}

Pada hasil tes analisis ini didapat data yang berupa angka-angka mengenai jumlah nilai yang diperoleh masing-masing siswa terhadap soal yang dikerjakan setelah menerapkan model pembelajaran STAD (Student Teams Achievement Division) pada mata pelajaran 
PPKn. Data yang diperoleh melalui tes dihitung jumlah nilai yang diperoleh masing-masing siswa dengan cara mengakumulasikan masing-masing nilai pada setiap item soal yang dijawab siswa. Berdasarkan rata-rata hasil belajar antara tes awal sebelum dilakukan tindakan dan siklus 1 yang diketahui pada awal tindakan mempunyai nilai rata-rata sebesar 38,5\% dan siklus 1 sebesar $65,5 \%$. Hal ini menunjukkan bahwa terjadi peningkatan prestasi belajar siswa setelah diterapkan model pembelajaran STAD pada mata pelajaran PKn. Namun berdasarkan nilai siswa pada siklus $1 \mathrm{di}$ atas, indikator keberhasilan tindakan perbaikan pada penelitian ini belum berhasil karena belum mencapai KKM 75. Masih terdapat 13 siswa yang belum mencapai nilai KKM, sehingga perlu dilanjutkan ke siklus II.

\section{Refleksi}

Dalam pembelajaran pada siklus 1 ini, tahap refleksi dilakukan oleh peneliti dan guru kolabolator untuk mengevaluasi hasil observasi partisipasi aktif siswa dan hasil pelaksanaan siklus 1 sebagai umpan balik setelah pembelajaran. Penggunaan model pembelajaran STAD meskipun belum maksimal, sebenarnya sudah menunjukkan peningkatan prestasi belajar PPKn siswa. Masih banyak siswa yang cenderung enggan untuk mengemukakan pendapat dan hal tersebut dikarenakan siswa belum terbiasa didalam menggunakan model pembelajaran STAD, sehingga masih banyak siswa yang pasif dalam mengikuti pembelajaran.

Pada pelaksanaan pembelajaran PPKn menggunakan Model pembelajaran STAD untuk meningkatkan prestasi belajar siswa pada siklus 1 belum sepenuhnya terlaksana dengan baik. Hal ini terjadi, mungkin dikarenakan siswa masih canggung dengan pembelajaran menggunakan model pembelajaran STAD.

Berdasarkan hasil refleksi tersebut, maka perlu adanya tindakan lanjutan untuk memperbaiki atau menyempurnakan pembelajaran dengan menggunakan model pembelajaran STAD. Hal dikarenakan belum tercapainya target tindakan yang diinginkan pada pelaksanaan tindakan pada siklus 1, maka peneliti melanjutkan tindakan pada siklus II.

\section{Siklus II}

\section{Perencanaan Tindakan}

Perencanaan tindakan yang dilakukan pada siklus II adalah sebagai berikut:

a. Mempersiapkan model pembelajaran STAD dengan materi yang masih sama dengan siklus 1 yaitu persamaan kedudukan warga negara. Mempersiapkan Rencanan Pelaksanaan Pembelajaran (RPP), RPP ini disusun sebagai pedoman guru atau peneliti dalam melaksanakan kegiatan pembelajaran di dalam kelas.

b. Mempersiapkan lembar observasi untuk mengetahui partisipasi aktif siswa selama proses belajar mengajar berlangsung. Lembar observasi ini digunakan sebagai pedoman guru atau peneliti di dalam mengamati siswa di kelas. Lembar ini akan diisi pada setiap pertemuan dan dibuat oleh peneliti.

c. Menyusun dan menyiapkan lembar angket repon siswa untuk mengetahui antusias siswa terhadap mata pelajaran PPKn. Lembar ini akan diisi oleh masing-masing siswa pada setiap pertemuan yaitu mulai kondisi awal, siklus 1dan siklus II yang dibuat oleh peneliti. 
d. Menyusun dan mempersiapkan soal-soal yang digunakan untuk mengukur prestasi belajar siswa setelah proses pembelajaran menggunakan model pembelajaran STAD berlangsung.

\section{Pelaksanaan Tindakan}

Langkah-langkah pelaksanaan tindakan pada siklus 1 adalah sebagai berikut:

1) Kegiatan Awal

a. Guru membuka pelajaran, mengawali dengan salam, mengabsen siswa, dan mengkondisikan kelas.

b. Guru memberikan motivasi dan mengajukkan pertanyaan yang berkaitan dengan materi pelajaran.

c. Guru menyampaikan kompetensi dasar dan tujuan pembelajaran.

d. Guru menyampaikan kegiatan yang meliputi kegiatan mengamati, menanya dan mengkomunikasikan.

e. Guru membagi siswa dalam beberapa kelompok yang tediri dari 4-5 orang.

f. Siswa menyimak penjelasan guru tentang model pembelajaran STAD.

2) Kegiatan Inti

a. Siswa mendengarkan penjelasan guru tentang materi persamaan kedudukan warga negara.

b. Siswa dengan difasilitasi oleh guru berdiskusi dengan kelompok masing-masing dan mengerjakan tugas yang diberikan guru.

c. Guru membimbing masing-masing kelompok untuk mengerjakan tugas yang diberikan kepada siswa.

d. Guru meminta siswa yang sudah bisa mengerjakan soal untuk menjelaskan kepada teman kelompoknya.

e. Guru memberi pertanyaan kepada seluruh siswa, pada saat menjawab siswa tidak boleh saling membantu.

f. Bersama-sama dengan peserta didik dan/atau sendiri membuat simpulan pelajaran.

3) Penutup

a. Melakukan penilaian dan/atau refleksi terhadap kegiatan yang sudah dilaksanakan.

b. Guru memberikan umpan balik positif dan penguatan dalam bentuk lisan, isyarat, maupun hadiah terhadap keberhasilan siswa.

c. Guru bersama siswa membaca do'a dan memberi salam.

\section{Hasil Angket Respon Siswa Siklus II}

Pada siklus II peneliti kembali membagikan angket respon siswa untuk mengetahui peningkatan antusias siswa terhadap mata pelajaran PPKn yang akan diisi oleh setiap siswa. Berikut adalah hasil angket respon siswa: 


\begin{tabular}{|c|c|c|c|}
\hline \multirow[b]{2}{*}{ Aspek Yang Diamati } & \multirow{2}{*}{$\begin{array}{l}\text { Jumlah } \\
\text { Siswa Total }\end{array}$} & \multicolumn{2}{|c|}{ Respon Siswa } \\
\hline & & $\begin{array}{c}\text { Jumlah } \\
\text { Siswa }\end{array}$ & $\begin{array}{c}\text { Prosentase } \\
(\%)\end{array}$ \\
\hline Saya senang dengan pelajaran $\mathrm{PKn}$ & 20 & 18 & 90 \\
\hline Pelajaran PKn menyenangkan & 20 & 17 & 85 \\
\hline $\begin{array}{l}\text { Dengan belajar PKn saya menjadi } \\
\text { bersemangat }\end{array}$ & 20 & 18 & 90 \\
\hline $\begin{array}{l}\text { Saya senang dengan metode diskusi dan } \\
\text { pemberian tugas }\end{array}$ & 20 & 19 & 95 \\
\hline $\begin{array}{l}\text { Dengan pembelajaran diskusi kelompok } \\
\text { saya bisa mengerjakan soal PKn }\end{array}$ & 20 & 16 & 80 \\
\hline $\begin{array}{l}\text { Model pembelajaran STAD sangat } \\
\text { cocok pada mata pelajaran PKn }\end{array}$ & 20 & 18 & 90 \\
\hline $\begin{array}{l}\text { Dengan diberinya model pembelajaran } \\
\text { STAD saya merasa sangat percaya diri }\end{array}$ & 20 & 18 & 90 \\
\hline $\begin{array}{l}\text { Saya terdorong untuk belajar dengan } \\
\text { menggunakan model pembelajaran } \\
\text { STAD }\end{array}$ & 20 & 17 & 85 \\
\hline $\begin{array}{l}\text { Dengan diterapkan model pembelajaran } \\
\text { STAD disiplin masuk sekolah } \\
\text { bertambah }\end{array}$ & 20 & 14 & 70 \\
\hline $\begin{array}{l}\text { Jika guru memberikan penghargaan / } \\
\text { reward terhadap pertanyaan, jawaban } \\
\text { dan hasil ulangan saya meningkat dan } \\
\text { belajar saya makin semangat }\end{array}$ & 20 & 19 & 95 \\
\hline
\end{tabular}

Dari data tabel di atas diketahui bahwa siswa yang senang dengan pelajaran PPKn sebanyak 90\%, pada siklus 1 sebanyak $75 \%$. Hal ini menunjukkan adanya peningkatan sebesar $15 \%$. Siswa yang menyetujui bahwa pelajaran PPKn menyenangkan sebanyak $85 \%$, pada siklus 1 sebanyak $70 \%$, terjadi peningkatan sebanyak $15 \%$. Siswa yang menyetujui bahwa dengan belajar PPKn menjadi bersemangat sebanyak 90\%, pada siklus 1 sebanyak $40 \%$. Ini menunjukkan adanya peningkatan sebesar 50\%. Siswa yang senang dengan metode diskusi dan pemberian tugas sebanyak 95\%, pada siklus 1 sebanyak 55\%, hal ini menunjukkan adanya peningkatan sebesar $40 \%$. Siswa yang menyetujui bahwa dengan pembelajaran model STAD bisa mengerjakan soal PPKn sebanyak $80 \%$, pada siklus 1 sebanyak 50\%. Hal ini menunjukkan bahwa setelah diterapkan model pembelajaran STAD sedikit ada peningkatan sebesar $30 \%$.

Siswa yang menyetujui bahwa model pembelajaran STAD sangat cocok pada mata pelajaran PPKn sebanyak 90\%, pada siklus 1 sebanyak 60\%, terjadi peningkatan sebesar $30 \%$. Siswa yang menyetujui bahwa dengan model pembelajaran STAD merasa percaya diri sebanyak $90 \%$, pada siklus 1 sebanyak $40 \%$, terjadi peningkatan sebesar $50 \%$. Siswa yang terdorong untuk belajar menggunakan model pembelajaran STAD sebanyak 85\%, pada siklus 1 sebanyak $40 \%$, ada peningkatan sebsar $45 \%$. Siswa yang bertambah menjadi disiplin masuk sekolah sebanyak $70 \%$, pada siklus 1 sebanyak $25 \%$, terjadi peningkatan sebesar $45 \%$, dan siswa yang menjadi semangat belajar dan hasil nilai ulangannya meningkat setelah guru memberikan penghargaan sebanyak 95\%, pada siklus 1 sebanyak $65 \%$, ini menunjukkan adanya peningkatan dari siklus 1 ke siklus II sebesar $30 \%$.

\section{Hasil Tes Siklus II}

Pada hasil tes analisis ini didapat data yang berupa angka-angka mengenai jumlah nilai yang diperoleh masing-masing siswa terhadap soal yang dikerjakan setelah menerapkan model pembelajaran STAD (Student Teams Achievement Division) pada mata pelajaran PPKn. 
Data yang diperoleh melalui tes dihitung jumlah nilai yang diperoleh masing-masing siswa dengan cara mengakumulasikan masing-masing nilai pada setiap item soal yang dijawab siswa. Adapun hasil perhitungannya sebagai berikut.

Tabel 5. Hasil Perhitungan Tes pada Siklus II

\begin{tabular}{|c|c|c|}
\hline No & NAMA SISWA & $\begin{array}{l}\text { HASIL TES } \\
\text { SIKILUS II }\end{array}$ \\
\hline 1 & Agustina Suklu & 100 \\
\hline 2 & Beatrik P. Angginop & 80 \\
\hline 3 & Calvin Stanly Zacharias & 80 \\
\hline 4 & Esau Yempolo & 80 \\
\hline 5 & Effa Sagisolo & 90 \\
\hline 6 & Henggelina Murpa & 90 \\
\hline 7 & Hengki Malasamuk & 60 \\
\hline 8 & Hendrika Malak & 100 \\
\hline 9 & Jhon Liwen Kolis & 70 \\
\hline 10 & Janet D. Ulim & 90 \\
\hline 11 & Kriston Yahya K. Rumbiak & 90 \\
\hline 12 & Lugi Galvani Klasjok & 80 \\
\hline 13 & Matelda Petrosina Kokmala & 100 \\
\hline 14 & Nahun Kasilit & 80 \\
\hline 15 & Novalin Kinfle & 100 \\
\hline 16 & Obet Sosior & 90 \\
\hline 17 & Obetedom Sudrafle & 80 \\
\hline 18 & Robert Robi Momot & 90 \\
\hline 19 & Ruthce Lobatrar & 100 \\
\hline 20 & Yunice Meder & 100 \\
\hline & Jumlah Nilai & 1750 \\
\hline & Rata-rata & 87,5 \\
\hline
\end{tabular}

Dalam menghitung nilai rata-rata siswa secara keseluruhan digunakan rumus:

$$
\mathbf{X}=\frac{\Sigma}{N} / \mathbf{X}=\frac{\text { jumlah nilai }}{\text { jumlah siswa }}
$$


Berdasarkan rata-rata hasil belajar antara tes siklus I dan siklus II yang diketahui pada tes siklus I mempunyai nilai rata-rata sebesar $65,5 \%$ dan siklus II sebesar $87,5 \%$. Hal ini menunjukkan bahwa terjadi peningkatan prestasi belajar siswa setelah diterapkan model pembelajaran STAD pada mata pelajaran PPKn. Berdasarkan rata-rata pada tes siklus II di atas kriteria ketuntasan belajar sudah tercapai yaitu lebih dari $85 \%$, yaitu kriteria ketuntasan belajar sebesar 90\%. Hal ini menunjukkan adanya pencapaian tingkat keberhasilan sesuai dengan kriteria keberhasilan yang telah ditetapkan.

\section{Refleksi}

Pada tahap refleksi peneliti bersama guru mengevaluasi hasil dari tes dan observasi, dari hasil pengamatan dan refleksi di sikuls II, maka penerapan model pembelajaran STAD ( Student Teams Achievement Division ) dapat meningkatkan prestasi belajar siswa dalam mata pelajaran PPKn. Pada hasil partisipasi aktif siswa, siswa telah berpartisipasi secara aktif dalam pembelajaran dan keaktifan siswa selama proses pembelajan berlangsung dapat dilihat pada dokumentasi berupa foto-foto yang telah terlampir dalam lampiran, sedangkan pada hasil belajar sebanyak 18 siswa sudah mencapai ketuntasan yang telah ditetapkan yaitu memperoleh nilai > 75 untuk masing-masing siswa pada siklus ke II. Jadi dari hasil pengamatan dan refleksi di siklus II penggunaan Model pembelajaran STAD dapat meningkatkan prestasi belajar siswa. Hal ini dikarenakan dengan menggunakan Model pembelajaran STAD, siswa lebih tertarik dan mempunyai motivasi yang tinggi untuk belajar. Keunggulan yang ada perlu dipertahankan untuk mendukung peningkatan dalam penggunaan media pembelajaran selanjutnya. Berdasarkan hasil tes dan hasil observasi dari siklus II yang telah terjadi peningkatan dari siklus I, peneliti dan guru sepakat bahwa penelitian ini tidak dilanjutkan ke siklus III.

\section{Kesimpulan dan Saran}

\subsection{Kesimpulan}

Berdasarkan hasil analisis data dan pembahasan yang telah peneliti lakukan, peningkatan prestasi belajar siswa dalam mata pelajaran PPKn melalui model pembelajaran STAD pada siswa kelas VIII SMP Lab. School Pulau Arar, dapat diambil kesimpulan sebagai berikut: Pembelajaran kooperatif STAD dapat meningkatkan prestasi belajar PPKn pada siswa kelas VIII SMP Lab. School Pulau Arar. Hal ini dapat dibuktikan dengan meningkatnya ketuntasan belajar siswa dari jumlah 20 siswa yang tuntas dengan KKM : 75. Pada kondisi awal sebelum diterapkan Model Pembelajaran STAD prestasi belajar PPKn kelas VIII SMP Lab. School Pulau Arar dikatakan rendah karena belum ada siswa yang nilainya memenuhi Kriteria Ketuntasan Minimal (KKM) yang telah ditentukan sekolah. Kemudian pada siklus I setelah diterapkan Model Pembelajaran STAD, prestasi belajar siswa mulai meningkat yaitu sebanyak 7 siswa memenuhi KKM. Kemudian setelah diadakan perbaikan pada siklus II ketuntasan belajar siswa meningkat menjadi 18 siswa yang tuntas memenuhi KKM. Jadi dengan demikian dapat dikatakan Model Pembelajaran STAD dapat meningkatkan prestasi belajar siswa dalam mata pelajaran PPKn. Dengan model yang diterapkan ini dalam dua siklus dapat meningkatkan prestasi belajar siswa sehingga pembelajaran menjadi hidup dan menyenangkan serta tidak membosankan.

\subsection{Saran}

Berdasarkan uraian-uraian di atas, maka peningkatan kualitas pembelajaran mutlak harus diupayakan semaksimal mungkin agar tercipta kegiatan pembelajaran yang memungkinkan siswa mencapai tujuan pembelajaran secara optimal, yaitu dengan menciptakan pembelajaran yang di dalamnya merupakan kondisi atau keadaan yang dialami siswa atau di sekitar siswa sehingga siswa termotivasi untuk berpartisipasi atau terlibat aktif dalam kegiatan pembelajaran, sehingga belajar siswa di kelas lebih optimal dan bermakna serta mudah dan menyenangkan. Oleh karena itu disarankan kepada : 
1. Guru : a) bersama siswa mengadakan refleksi untuk mengetahui kesan-kesan atau respon siswa terhadap pembelajaran yang baru berlangsung; b) senantiasa menggunakan Pembelajaran kooperatif STAD sehingga siswa merasa akrab dengan pelajaran PKn serta dapat diujicoba pada pelajaran lainnya.

2. Siswa; a) memanfaatkan sumber dan media belajar secara optimal untuk lebih memahami materi; b) selalu minta petunjuk jika mengalami kesulitan dalam belajar.

3. Sekolah / pemerintah sebagai pengambil kebijakan pendidikan: a) meningkatkan kualitas tenaga kependidikan dalam hal ini adalah guru, agar kualitas tenaga kependidikan lebih bermutu; b) meningkatkan sarana dan prasarana yang memadai baik dari segi kuantitas maupun kualitas sebagai penunjang keberhasilan proses belajar mengajar.

\section{Daftar Pustaka}

Aan, H. (2012). Pengembangan Profesi Guru. Bandung: CV Pustaka Setia

Bambang, S. dkk.(2017). Pendidikan Kewarganegaraan SMP Kelas VIII. Jakarta:Erlangga

Benny, A. (2009). Model Desain Sistem Pembelajaran. JakartaL: Dian Rakyat

E. Soelasmini, Undang - Undang Dasar 1945. Bandung: Wacana Adhitya.

Isjoni. (2012). Pembelajaran Kooperatif. Yogyakarta: Pustaka Pelajar

Martinis, Y. (2013). Strategi dan Metode dalam Model Pembelajaran. Jakarta: GP Press Group

SISDIKNAS. (2013). Undang-Undang Sistem Pendidikan Nasional. Jakarta: Karisma

Suharsimi, A. dkk. (2010). Penelitian Tindakan Kelas. Jakarta: Bumi Aksara

Trianto, Y. (2013). Model-Model Pembelajaran Inovatif berorientasi Konstruktivistik. Jakarta: Prestasi Pustaka

Zainal, A. dkk. (2011). Penelitian Tindakan Kelas. Bandung: Yrama Widya

http://eprints.uns.ac.id. Penelitian Tindakan Kelas. 17 Oktober 2018.

http.//educationesia.blogspot.com. Upaya Meningkatkan Prestasi Belajar.html. 17 Oktober 2018. 